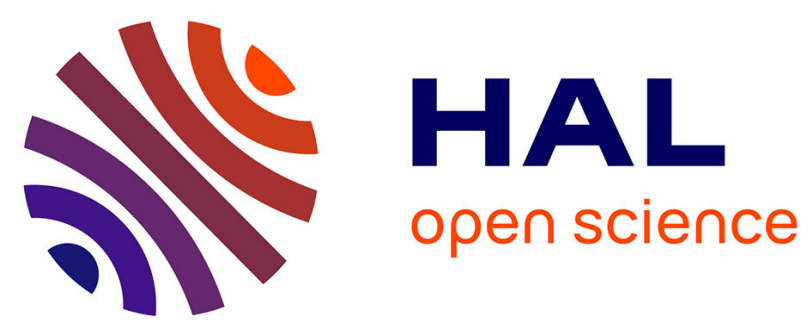

\title{
Climatic controls on interannual variability of precipitation $\delta 18$ O: Simulated influence of temperature, precipitation amount, and vapor source region
} Julia Cole, David Rind, Robert Webb, Jean Jouzel, Richard Healy

\section{- To cite this version:}

Julia Cole, David Rind, Robert Webb, Jean Jouzel, Richard Healy. Climatic controls on interannual variability of precipitation $\delta 18 \mathrm{O}$ : Simulated influence of temperature, precipitation amount, and vapor source region. Journal of Geophysical Research: Atmospheres, 1999, 104 (D12), pp.1422314235. 10.1029/1999JD900182 . hal-03110383

\section{HAL Id: hal-03110383 \\ https://hal.science/hal-03110383}

Submitted on 25 Jan 2021

HAL is a multi-disciplinary open access archive for the deposit and dissemination of scientific research documents, whether they are published or not. The documents may come from teaching and research institutions in France or abroad, or from public or private research centers.
L'archive ouverte pluridisciplinaire HAL, est destinée au dépôt et à la diffusion de documents scientifiques de niveau recherche, publiés ou non, émanant des établissements d'enseignement et de recherche français ou étrangers, des laboratoires publics ou privés. 


\title{
Climatic controls on interannual variability of precipitation $\delta^{18} \mathrm{O}$ : Simulated influence of temperature, precipitation amount, and vapor source region
}

\author{
Julia E. Cole ${ }^{1}$, David Rind ${ }^{2}$, Robert S. Webb ${ }^{3}$, Jean Jouzel ${ }^{4}$, Richard Healy ${ }^{5}$
}

\begin{abstract}
We use an atmospheric GCM that incorporates stable isotopes and regional vapor source tracers in the hydrologic cycle to explore the relationship between interannual variability in climate and precipitation $\delta^{18} \mathrm{O}$ globally. On the basis of a 12-year simulation forced by observed sea surface temperatures (SSTs), we identify changes in the amount of precipitation and in the contributions of local and nearby vapor sources as the most important determinants of simulated interannual isotopic changes. The model simulates weak positive correlation between temperature and isotopic variability only in certain continental regions, mostly in the extratropics.

Comparison with long observed records of isotopes and climate indicates that the model simulates realistic patterns of temperature-isotope correlation but may overestimate the isotopic influence of precipitation amount. Perturbations in circulation patterns that alter the transport and mixing of air masses at a site also change the relative contributions of vapor from different source regions. Simulated changes in vapor source regions are large, reaching $\pm 10-15 \%$ of the total precipitation, and cause significant isotopic variability in nearly all grid cells. Our results suggest that shifts among vapor sources may provide an important control on the interannual isotopic variability observed in modern precipitation and paleoclimatic records. The isotopic variability simulated in this experiment results from the interaction of several aspects of climate. Interannual temperature variability generally involves circulation changes that alter air mass transport, vapor source regions, and condensation history; this advective mechanism may explain the relative weakness of temperature-isotope correlations in both the model and the observations.
\end{abstract}

\section{Introduction}

Climatic factors govern the stable isotopic content of precipitation, and the relationship between specific parameters such as temperature or precipitation amount and precipitation isotopic content allows the reconstruction of past climate from paleoclimatic archives such as ice cores. The pioneering work of Dansgaard [1964] first documented that the annual average isotopic content of precipitation correlates directly with annual temperature for sites with temperature below $15^{\circ} \mathrm{C}$ and inversely with annual precipitation amount in warmer locations. Subsequent work has expanded Dansgaard's spatial analyses to the time domain, demonstrating correlation of temporal isotopic and climatic variability in certain locations [Rozanski et al., 1992; Cuffey et al., 1994; Shuman et al., 1995; Yao et al., 1996]. However, recent summaries of ice core and precipitation isotopic data illustrate that for many regions, temporal variations in the

\footnotetext{
${ }^{\text {IDepartment }}$ of Geological Sciences/INSTAAR/PAOS, University of Colorado, Boulder.

${ }^{2}$ NASA Goddard Institute for Space Studies, New York.

${ }^{3}$ Paleoclimatology Program, NOAA/NGDC, Boulder, Colorado and INSTAAR, University of Colorado, Boulder.

${ }^{+}$Commissariat à l'Energie Atomique/CNRS, Gif-sur-Yvette, France.

${ }^{5}$ Woods Hole Oceanographic Institution, Woods Hole, Massachusetts
}

Copyright 1999 by the American Geophysical Union

Paper number 1999JD900182

0148-0227/99/1999JD900182\$09.00 isotopic content of precipitation do not correlate strongly or uniquely with temperature or precipitation amount changes, particularly on interannual and longer timescales [Rozanski et al., 1992, 1993; Cole, 1992; Yao et al., 1996]. Instead, temperature changes combine with other climatic variations to produce a mixed signal of climate variability in the isotopic content of precipitation and thus of paleoisotopic records [White et al., 1997]. Changes in vapor source regions, air mass mixing, postcondensation processes, and continental vapor recycling all contribute to the temporal variation of precipitation $\delta^{18} \mathrm{O}$ or $\delta \mathrm{D}$ [Dansgaard et al., 1964; Salati and Vose, 1984; Rozanski et al., 1982; Gat, 1980; Grootes et al., 1989; Koster et al., 1993; Charles et al., 1994; Yakir et al., 1996]. Changing the seasonality of precipitation can alter annual means independently of other climate factors [Steig et al., 1994; Krinner et al., 1998]. All of these factors may vary in their contributions to isotopic variability, regionally and temporally, complicating paleoclimatic interpretations of isotopic data.

\subsection{Climate-Isotope Relationships}

The source of the temperature-isotope relationship observed by Dansgaard [1964] and others is twofold. First, as air masses cool, they lose more moisture through condensation, which preferentially removes heavier isotopes. Thus the vapor becomes increasingly depleted in heavy isotopes as cooling and condensation proceed. Isotopic fractionation associated with the extent of condensation depends most directly on the temperature difference from vapor source to condensation, rather than on the local 
temperature of condensation. Second, the fractionation factor $\alpha$, which determines the relative partitioning of heavy and light isotopes during a phase transition, also depends upon temperature. The spatial relationship between annual mean temperature and precipitation isotopic content results from the combination of these two processes. However, the observed linearity of this relationship does not arise directly from either or both of these factors but according to simple isotopic models appears to be fortuitous [Jouzel and Merlivat, 1984]. Significant scatter about the spatial temperature-isotope relationship may result from variable contributions of vapor from oceanic and continental sources [Koster et al., 1993] and from the tendency of precipitation in continental interiors to be more depleted than coastal precipitation, because of preferential removal of isotopically enriched vapor from the parcel as it moves inland. Jouzel et al. [1997] discuss the potential influences of these and other complicating factors with respect to isotopic variability observed in the Greenland ice sheet.

The correlation between precipitation amount and $\delta^{18} \mathrm{O}$ results from the removal of isotopically enriched vapor as condensation proceeds, leaving behind an increasingly light vapor parcel. Thus as more precipitation forms from a given vapor parcel, subsequent precipitation will become increasingly lighter. This effect is amplified by the evaporation of droplets beneath the cloud base, which removes lighter isotopes preferentially. This process occurs more extensively when the air below the cloud is not fully saturated with vapor, a situation characteristic of less intense precipitation events [Gat, 1980]. Isotopic exchange between droplet and vapor can also contribute to the amount effect.

A third type of influence on the isotopic content of precipitation derives from the extent of condensation experienced by the vapor parcel along its trajectory from source to condensation. Locally derived water vapor has undergone less condensation and fractionation than vapor transported from great distances, so precipitation resulting from local vapor will tend to be isotopically heavier than that derived from distant sources. In addition to the distance from a source, the type of source is also isotopically significant: vapor that evaporates from standing water is isotopically fractionated toward lighter values, whereas vapor that enters the atmosphere through evapotranspiration from vegetated land surfaces is not fractionated [Zimmerman et al., 1967] but retains the composition of the groundwater (determined primarily by the long-term average isotopic composition of precipitation). We will call this influence the source effect, bearing in mind that it involves the type and distance of moisture source as well as the condensation history of the air mass. Bromwich and Weaver [1983] discuss evidence for this effect in coastal Antarctica, where seasonally varying sea ice position creates seasonally varying distance to the vapor source, and Koster et al. [1993] discuss the influence of evapotranspirated moisture on the global temperature-isotope relationship.

\subsection{Modeling Approaches}

Attempts to improve interpretation of isotopic records by quantifying the processes that govern isotopic variability have generally utilized simple Rayleigh models, which offer theoretical confirmation of the temperature and amount effects [Gedzelman and Lawrence, 1982; Jouzel and Merlivat,
1984; Dansgaard et al., 1989; Petit et al., 1991]. However, additional factors, such as vapor source regions, mixing of air masses with different sources and transport histories, and post-condensation processes, probably vary as a function of climate. Simple Rayleigh models do not incorporate these factors interactively but instead either evaluate a range of fixed options or assume that they remain constant.

Atmospheric general circulation models (GCMs) that include isotopic and geographic tracers in the hydrologic cycle provide a more complete means to evaluate the processes governing variations in the isotopic content of precipitation [Joussaume et al., 1984; Jouzel et al., 1987; Hoffmann and Heimann, 1993; Hoffmann et al., 1999; R. Mathieu et al., manuscript in preparation, hereafter referred to as M99]. Tracer-capable GCMs incorporate all the processes that lead to the deposition of precipitation and calculate isotopic averages from the results of individual (variable) precipitation events. GCMs can also track the relative contributions of different vapor source regions to precipitation at any grid cell within the GCM (geographic tracers) [Koster et al., 1986; Joussaume et al., 1986], an important capability as this aspect of the hydrologic cycle is difficult to observe. The model tracks vapor from a specified source region starting at evaporation and continuing until the vapor condenses and falls as precipitation, when the source "tag" is lost. At each grid box, the model then calculates how much precipitation originated from each of the specified sources. Thus tracer-capable GCMs enable investigation of the global relationship between climatic and isotopic variability and of how changes in vapor source regions impact the isotopic content of precipitation both locally and remotely.

Tracer GCMs tend to produce reasonable large-scale fields of precipitation isotopic content, reproducing well the observed spatial correlations between precipitation $\delta^{18} \mathrm{O}$ and temperature, and the tendency for isotopic depletion in continental interiors and in regions of intense tropical rainfall [e.g. Joussaume et al., 1984; Jouzel et al., 1987; Hoffmann and Heimann, 1993; M99]. Regional patterns may differ from observations; these discrepancies can often be attributed to factors such as insufficient resolution to produce significant continentality or orography, or to an inadequate simulation of surface climate. In other cases, datamodel discrepancies are not easily understood.

Tracer GCMs are beginning to be used to explore temporal as well as spatial isotopic variability. These models have been applied to evaluate isotopic fields associated with the last glacial maximum period [Joussaume and Jouzel, 1993; Jouzel et al., 1994] and have allowed examination of changing vapor sources to the Greenland ice sheet during deglaciation [Charles et al., 1994]. Jouzel et al. [1997] use tracer GCM results, in combination with simpler models, to evaluate the validity of temperature reconstructions from Greenland ice core isotopic records. Addressing more recent time scales, Cole et al. [1993] used a pair of contrasting periods (1955-1956 and 1982-1983) to evaluate the isotopeclimate relationship associated with interannual variability, and Hoffmann et al. [1998] assessed the relationship between climate and isotopic variability for simulated interannual variability over a continuous 10-year period (1979-1988). Our study builds on previous work to evaluate how variations in vapor source regions, as well as temperature and precipitation, contribute to global patterns of simulated 
interannual isotopic variability over a 13-year transient experiment spanning 1979-1991.

\section{Model Experiments}

We used the NASA-GISS model 2 at $8^{\circ} \times 10^{\circ}$ resolution [Hansen et al., 1983] with isotopic and geographic tracer capabilities [Koster et al., 1986; Jouzel et al., 1987, 1991] to explore the processes that control interannual isotopic variability. The model follows water isotopic and geographic source tracers throughout all aspects of the model's hydrologic cycle, calculates the appropriate isotopic fractionation on all phase transitions, and accounts for tracer transfer among and storage within reservoirs of the hydrologic cycle. No fractionation is assumed on evaporation from land surfaces [Zimmerman et al., 1967], and the ocean's isotopic composition remains fixed. Geographic tracers identify the vapor evaporating from user-specified source regions, and the model tracks this vapor through the atmosphere's hydrologic cycle until it falls again to the surface. Previous work demonstrates that simulated isotopic fields agree reasonably well with observations [Jouzel et al., 1987, 1991], although the relatively coarse resolution excludes many regional features, particularly those associated with topographic extremes. Differences between simulated fields and observations do not compromise our evaluation of the processes associated with isotopic variability, as we focus here on the relationship between simulated climate and isotopic anomalies within the model.

For this study, the model was run for 13 years, forced with observed sea surface temperature (SST) anomalies between 1979 and 1991, in order to generate reasonable interannual variability. The analysis period includes two realizations of El Niño/Southern Oscillation (ENSO) warm phases (19821983 and 1986-1987) and one cool phase (1988). Previous single-month experiments using prescribed SST anomalies associated with ENSO warm and cool phases indicate that the model's atmospheric response to these anomalies mimics

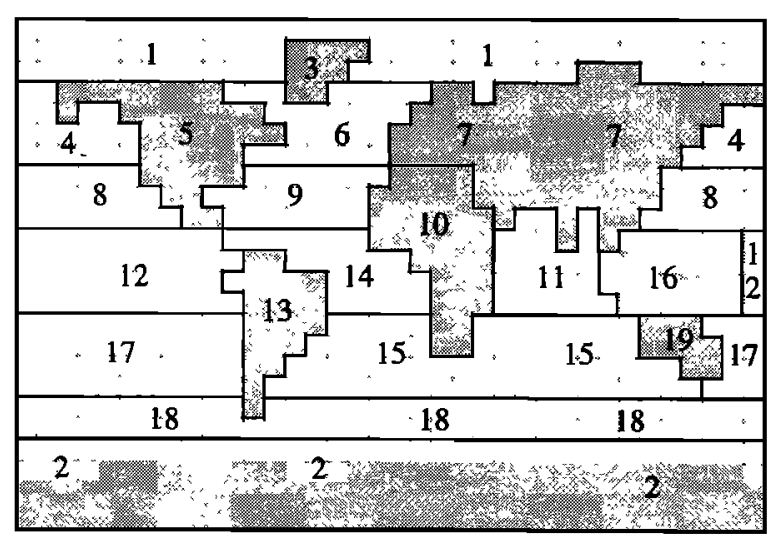

Figure 1. Map indicating model resolution $\left(8^{\circ}\right.$ latitude $\times 10^{\circ}$ longitude) and the outlines of the geographic regions specified as sources of water vapor to be traced throughout the hydrologic cycle (numbers 1-19). Shaded regions represent approximate continental outlines, and geographic sources are indicated by solid outlines. The model represents coastal boxes with fractional specifications for land and ocean coverage. observed ENSO variability (e.g., pressure and precipitation fields and Walker circulation intensity [Cole et al., 1993]). That study included isotopic diagnostics but examined only July and January anomalies associated with prescribed SSTs from 1982-1983 (an ENSO warm phase) and 1955-1956 (an ENSO cool phase). Our current work expands on that study by including 13 years of prescribed SST as forcing, enabling more robust evaluation of temporal climate-isotope correlation at each grid point, and by including a more detailed specification of vapor source regions. In these simulations the model tracks the isotopic content of precipitation and the contributions of 19 geographic regions to local precipitation (Figure 1). The results allow assessment of how a broad array of climatic factors (including changing vapor source regions) influences interannual variations in the isotopic content of precipitation.

\section{Results}

In this study we focus on the relationship of simulated precipitation $\delta^{18} \mathrm{O}$ to climatic (including source region) changes. We evaluate climate-isotope and source-isotope correlations in model years 2-13 (1980-1991), thus avoiding anomalies associated with model equilibration during the first year. We use monthly anomalies in all analyses to avoid correlation imposed by seasonality (i.e., for each month, we subtract the mean monthly value of that parameter in order to remove the mean seasonal cycle). For reference, Plate 1 illustrates the average patterns of temperature, precipitation, and precipitation $\delta^{18} \mathrm{O}$ produced by the model and the standard deviations of these quantities. Variance in temperature and precipitation $\delta^{18} \mathrm{O}$ is concentrated in high latitudes and over continents; precipitation variance is highest in tropical regions, particularly over the equatorial oceans. Values of $\delta^{18} \mathrm{O}$ have been weighted by the amount of precipitation, as unweighted averaging of monthly values would over-represent values from drier relative to wetter months.

Plate 2 illustrates the average contribution of the specified source regions to precipitation in each grid cell. These results indicate that in most cases, over $75 \%$ of the modeled precipitation over the ocean was derived from a local vapor source, except at high latitudes. In contrast, for continental regions, generally less than $70 \%$ of the precipitation is derived from local moisture recycling (evapotranspiration), with the balance originating from nonlocal moisture sources. Tropical continents generally have a greater contribution of local vapor to the local precipitation than do higher-latitude continents, presumably due to greater evapotranspiration in warmer climates and to the greater saturation vapor pressure of a warmer atmosphere.

At each grid cell, we calculate the linear correlation $r$ over 144 consecutive months (in certain arid regions, certain months have no precipitation and the number of months is slightly below 144). Plate 3 shows the correlation between monthly anomalies of $\delta^{18} \mathrm{O}$ of precipitation and local temperature (Plate 3a) and precipitation amount (Plate 3b). Only correlations significant at better than $98 \%$ are shown. The classic temperature-isotope correlation [Dansgaard, 1964] is positive; the model simulates weak to moderate $(r<$ $0.5)$ positive temperature- $\delta{ }^{18} \mathrm{O}$ correlations concentrated in continental, middle- to high-latitude regions, although certain tropical regions also show significant positive 

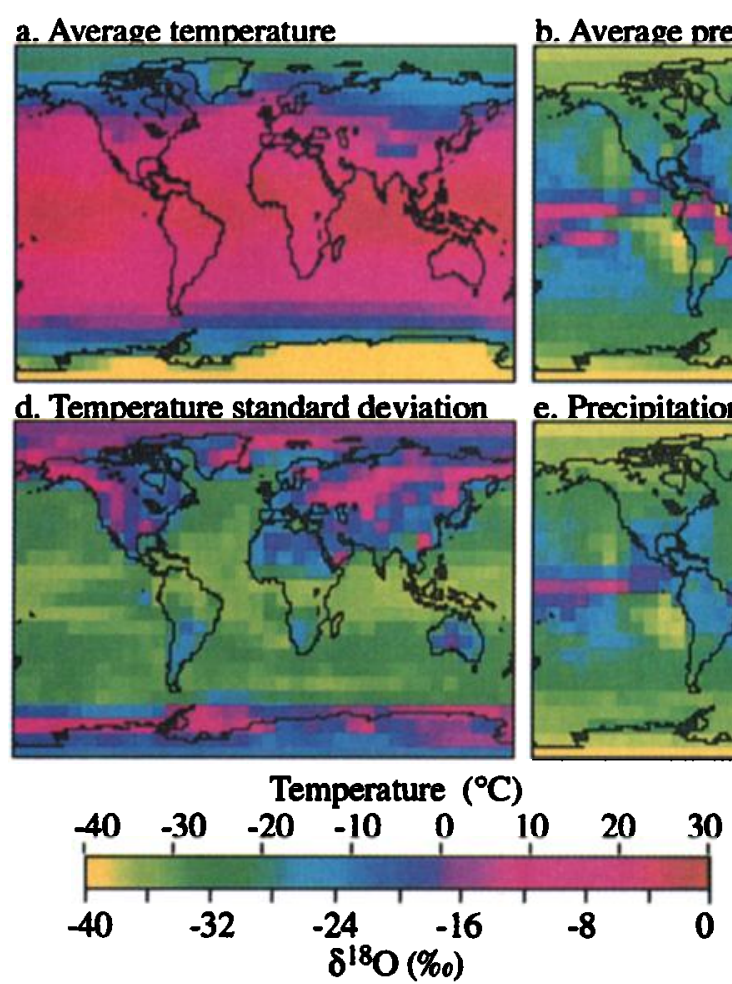
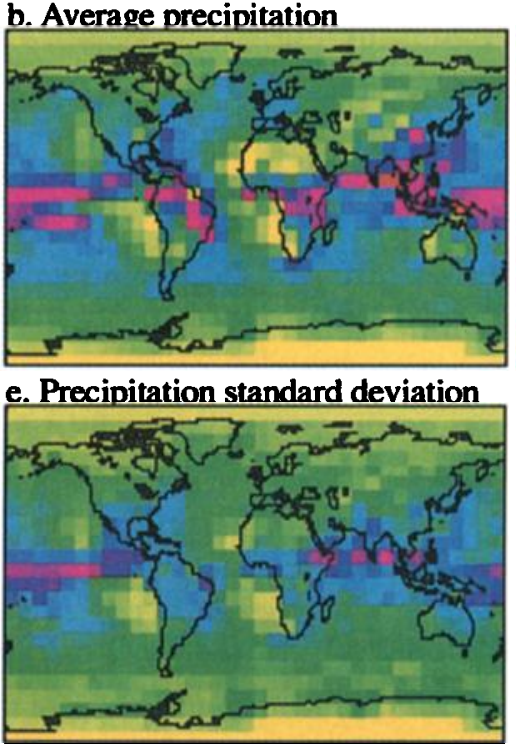
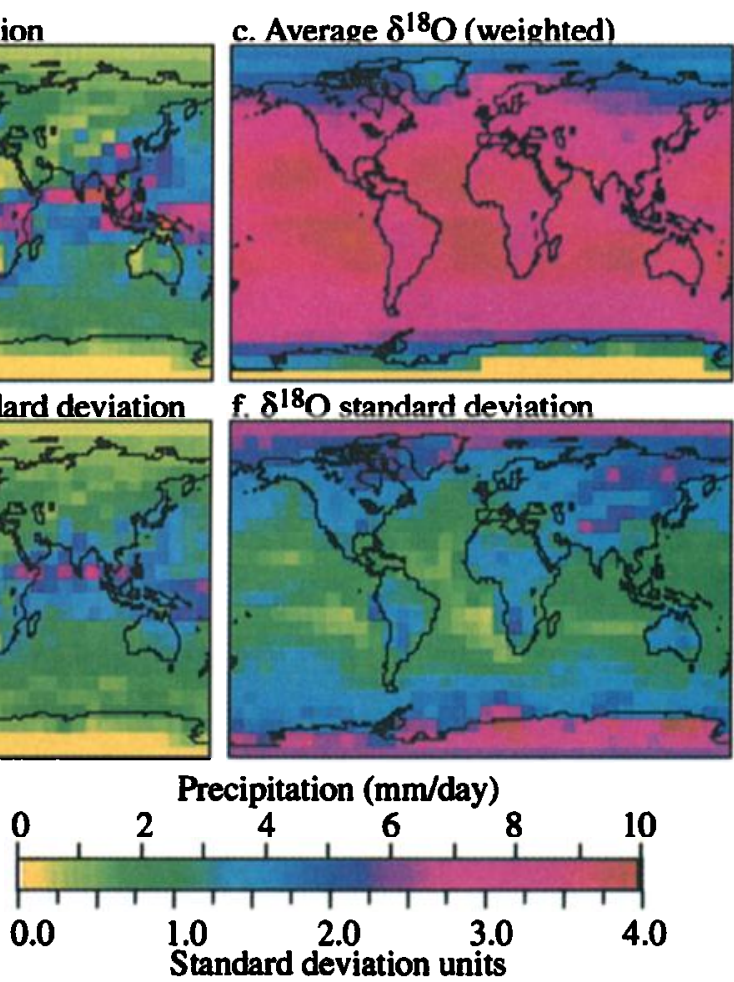

Plate 1. Maps of mean temperature, precipitation, and precipitation $\delta^{18} \mathrm{O}$ for the 12 years of model run analyzed in this study (Plates $1 \mathrm{a}-1 \mathrm{c}$ ) and the standard deviations of temperature, precipitation, and precipitation $\delta^{18} \mathrm{O}$ based on monthly anomalies (mean seasonal cycle removed; Plates 1d-1f) for the 12-year simulation. Precipitation $\delta^{18} \mathrm{O}$ values are weighted by the amount of precipitation.

correlation. Negative temperature- $\delta^{18} \mathrm{O}$ correlations throughout the low- to middle-latitude oceans reach levels of -0.7 and reflect the strong relationship between warmer and wetter conditions, particularly in the equatorial Pacific.

From isotopic theory (the classic "amount effect") [Dansgaard, 1964], we expect an inverse relationship between precipitation amount and $\delta^{18} \mathrm{O}$. The simulated precipitation amount- $\delta^{18} \mathrm{O}$ relationship is strong and extensive, influencing mostly oceanic sites. Values reach -0.8 in the tropical oceans and show a widespread tendency for lower significant values (between -0.2 and -0.5 ) over many continental regions. Tropical continents in particular show strong simulated amount effects. Over Antarctica the model simulates a positive amount- $\delta^{18} \mathrm{O}$ correlation. A possible explanation for this anomaly is that temperature is strongly variable there, whereas precipitation amount shows little variability (Plate 1) and is strongly correlated with temperature (not shown). Thus the temperature effect dominates the isotopic variability. The opposite situation prevails, for example, in the tropical Pacific, where low temperature variability is overshadowed isotopically by strong precipitation variability, and the amount effect prevails.

We also explore the degree of correlation between precipitation $\delta^{18} \mathrm{O}$ and the contribution of vapor from the geographic source regions shown in Figure 1 (Plate 4). If the vapor source under consideration constitutes less than $2 \%$ of the total precipitation, we have excluded it from this analysis in order to avoid spurious correlations associated with very small amounts of vapor. Overall, we find that precipitation $\delta^{18} \mathrm{O}$ in a given location tends to correlate positively with the contribution of vapor from that region and inversely with the contribution of more distant upstream sources, as expected if vapor becomes progressively lighter as it travels farther and condensation proceeds. This pattern is clearly seen in the bottom right-hand panel of Plate 4, which maps the correlation of precipitation $\delta^{18} \mathrm{O}$ with the contribution of the local source region. The source- $\delta{ }^{18} \mathrm{O}$ correlations are generally weaker over continents than over the ocean.

To identify the dominant controls on precipitation $\delta^{18} \mathrm{O}$ variability, we tabulated the number of model grid cells where each of the variables under consideration (temperature, precipitation, the contribution of each source in Figure 1, and the contribution of local moisture) correlated significantly with the isotopic variance over the 12-year simulation (Table 1). We chose a cutoff correlation value of $r= \pm 0.2$, which is significant at the $98.4 \%$ level when both positive and negative correlations are considered. Variations in precipitation amount and in the contribution of vapor from local sources provide the dominant controls on interannual isotopic variability in our simulations; these factors correlated with isotopic variability over the largest regions (74 and $70 \%$ of all grid cells, respectively). Regionally, the influence of specific source regions plays a comparably important role. The influence of temperature was far less important than that of precipitation amount and vapor source, with positive $r$ values reaching statistical significance in only $12.5 \%$ of the grid cells. 

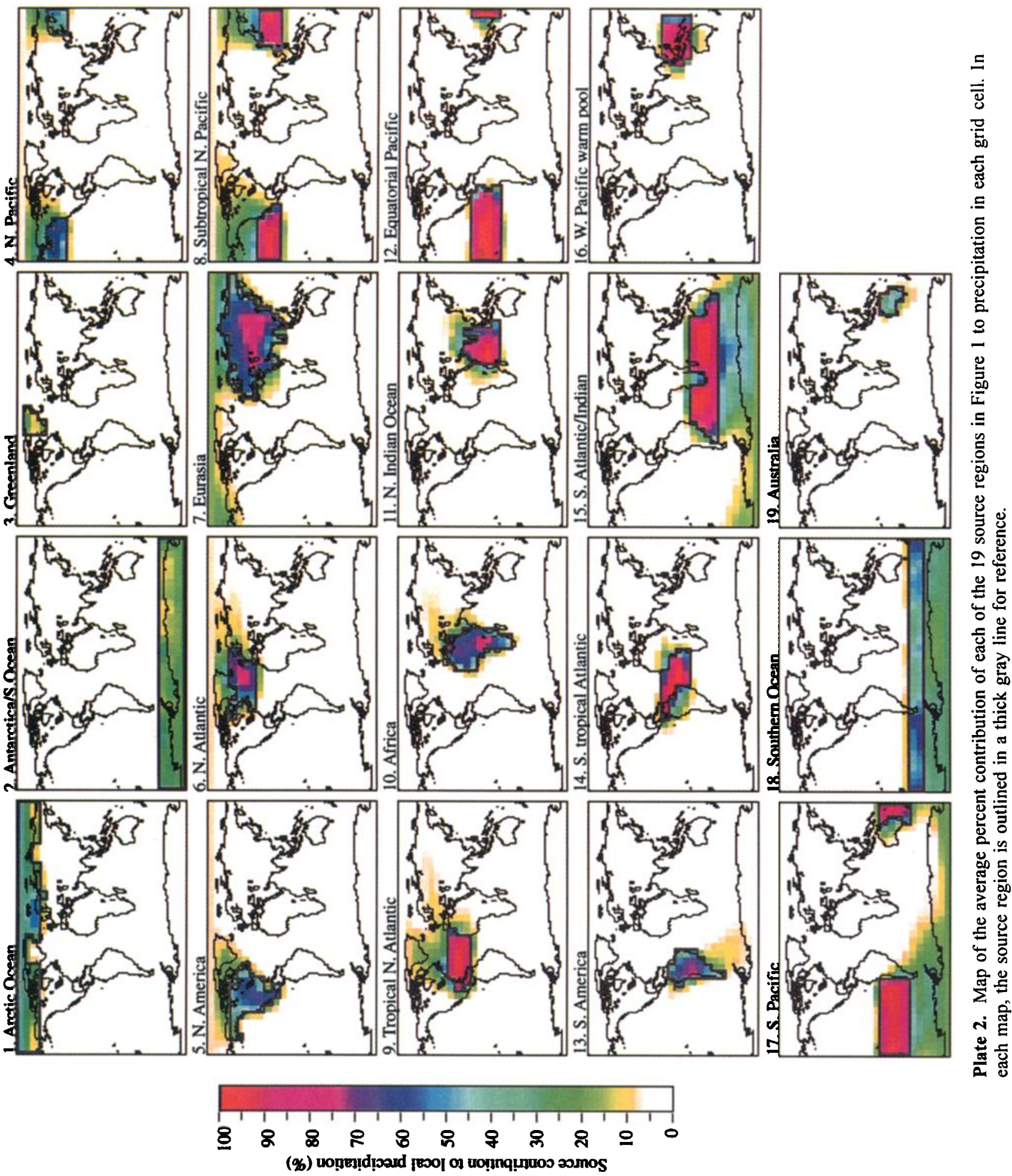


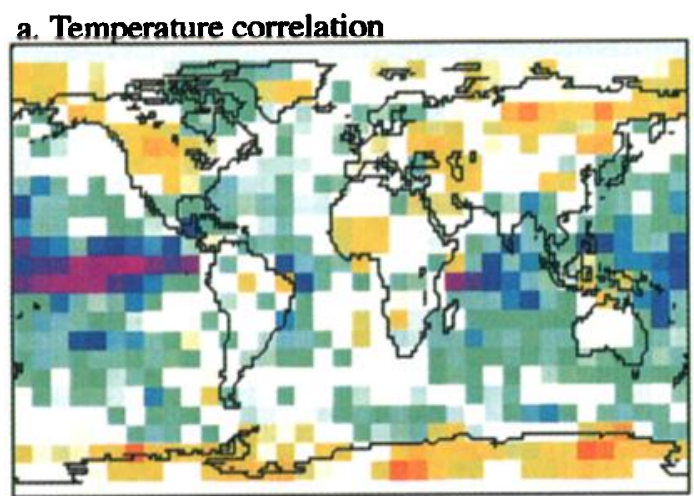

b. Precinitation amount correlation

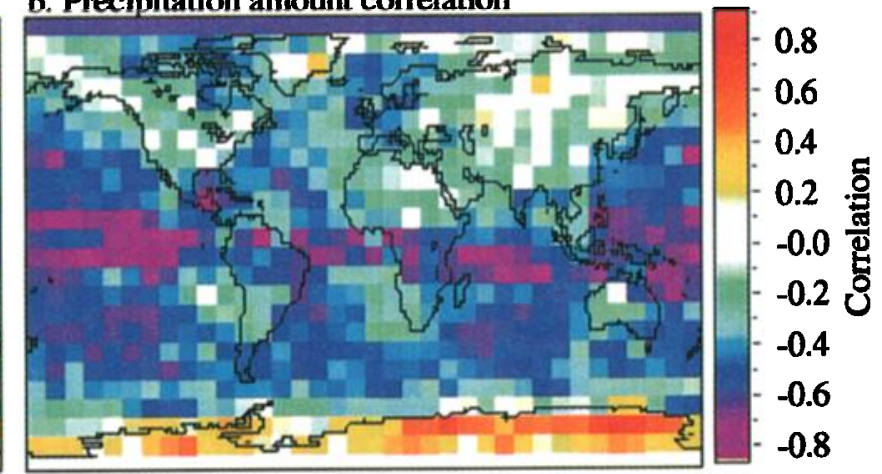

Plate 3. Mapped correlation coefficients between isotopic variability and (a) temperature and (b) precipitation, using monthly anomalies of model output (seasonal cycle removed). We chose a cutoff correlation value of \pm 0.2 , which is significant at the $98.4 \%$ level.

We observe a statistically significant correlation between precipitation $\delta^{18} \mathrm{O}$ and climate for every climate parameter we investigated (temperature, precipitation, and source regions), somewhere on the globe. However, although a correlation coefficient of 0.2 may have statistical significance, it represents only $4 \%$ of the variance in common and thus offers little in the way of ability to reconstruct climate. To assess the paleoclimatically relevant question of which parameters would provide univariate reconstructions of climate variability that explained a specified amount of variance, we also noted how many grid cells achieved an $r$ value of 0.55 (explaining an arbitrarily chosen $30 \%$ of the isotopic variance with a single climatic parameter). Only precipitation amount and source regions reached these levels at any locations; direct correlations between temperature and isotopic variability were almost always below 0.5 .

\section{Discussion}

\subsection{Validation of Simulated Moisture Source Distributions}

Although observational studies have not produced a global description of vapor source regions for global precipitation in the detail needed to validate GCM estimates, regional studies have inferred moisture source regions from both dynamical climate variables (e.g., wind and humidity) and precipitation isotopic data. On the global scale, our results agree with the empirical conclusion that subtropical ocean regions provide substantial moisture for precipitation poleward of those regions in each hemisphere [Peixoto and Oort, 1993]. Brubaker et al. [1994] diagnosed oceanic sources of vapor to the Americas, and our results agree with their major conclusions: Pacific and Atlantic sources provide comparable contributions of oceanic vapor to North America; over northeastern South America the primary oceanic source of vapor is the tropical Atlantic, and in southernmost South America the dominant oceanic source of moisture is Pacific vapor carried in by the westerlies. For Antarctic precipitation, observational analyses are ambiguous: water balance studies indicate tropical-to-subtropical source regions, whereas oxygen isotope studies of Antarctic precipitation suggest subtropical-to-subpolar moisture sources [Bromwich, 1988]. Our results suggest substantial contributions from all
Southern Hemisphere ocean moisture sources (Plate 2), with about half originating from poleward of $50^{\circ} \mathrm{S}$ and half from ocean sources between $17-50^{\circ} \mathrm{S}$. Koster et al. [1992] use the GISS GCM to provide a more detailed analysis of vapor sources for July Antarctic precipitation.

Estimates of continental recycling derived from the NASAGISS model tend to reach relatively high values, over $50 \%$ in continental interiors (Plate 2) [see also Koster et al., 1993]. Recent observational estimates of annual precipitation recycling range from 10-40\% [Brubaker et al., 1993; Eltahir and Bras, 1996]. Isotopic measurements of precipitation along transects into continents also indicate substantial contributions of moisture from groundwater, with values of $20-50 \%$ for regions substantially smaller than our specified sources [Salati et al., 1979; Rozanski et al., 1982; Ingraham and Taylor, 1991]. Eltahir and Bras [1996] note that estimates of annual precipitation recycling depend on the spatial scale of the analysis; higher recycling ratios are associated with larger areas. The high estimates of continental recycling in our model results ( $>50 \%$ in continental interiors) can be explained in part by our specification of large continental source regions (Figure 1).

\subsection{Comparison with Long Observed Isotopic Records}

How realistic are the simulated climate-isotope relationships? Long records of isotopic and climatic variability exist at several sites, a product of the International Atomic Energy Agency (IAEA) monitoring network whose results have been described by Dansgaard [1964] and Rozanski et al. [1993]. From the Global Network of Isotopes in Precipitation (GNIP) database [IAEAWMO, 1998], we selected those stations that included at least 10 years of $\delta^{18} \mathrm{O}$ and climatic data between 1957 and 1992 to compare isotopeclimate correlations with our model results. Many of these stations had fewer than 120 observations, often because of the lack of rainfall in dry months of arid seasons; we retained these stations, as lack of rainfall occurs in some GCM grid cells also. Although vapor source information is unavailable, the IAEA stations include local temperature and precipitation amount as well as isotopic data. After removing the seasonal cycle, we calculated the correlation between monthly anomalies of precipitation $\delta^{18} \mathrm{O}$ and local climate. Plate 5 


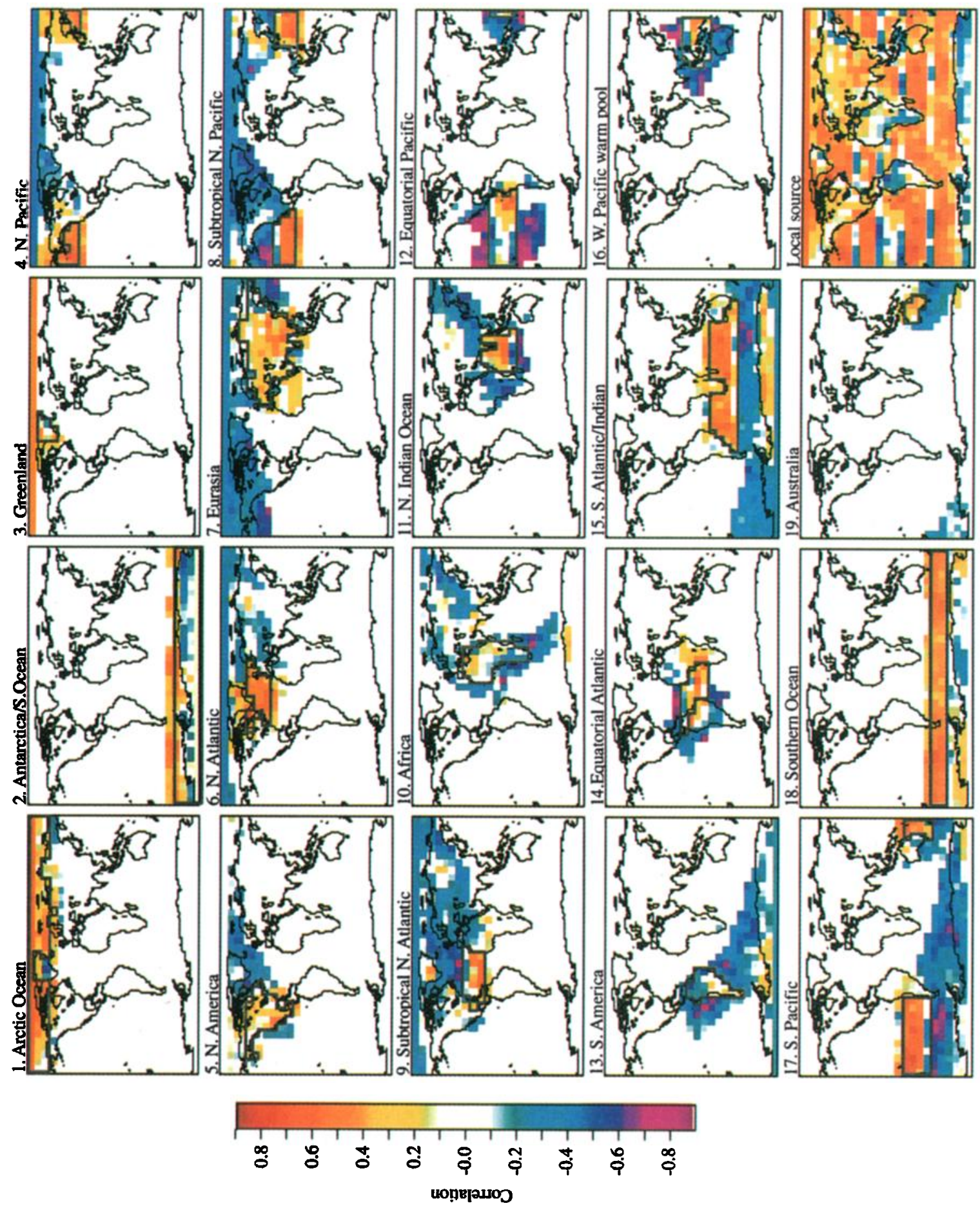

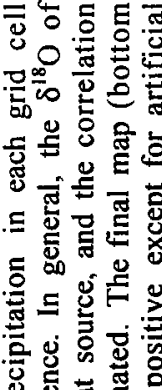

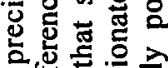

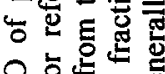

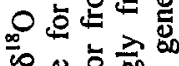

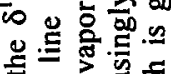

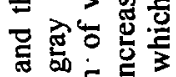
능 定至 它. 割造 홀 을 늘 응. 을

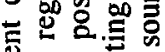

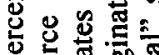
可 证

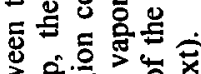

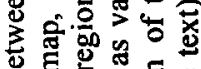

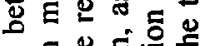

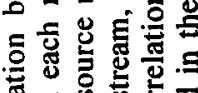

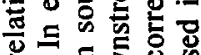

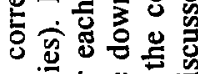
范

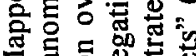
$\sum$ 可产密

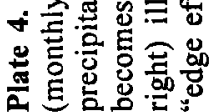


Table 1. Influence of Simulated Climate and Source Parameters on Variability of the Isotopic Content of Precipitation

\begin{tabular}{|c|c|c|c|c|c|}
\hline $\begin{array}{c}\text { Potential Factor } \\
\text { Influencing } \\
\text { Precipitation } \delta^{18} \mathrm{O} \\
\text { (Climate, Source Regions) }\end{array}$ & $\begin{array}{l}\text { Number of } \\
\text { Grid Cells } \\
\text { Potentially } \\
\text { Influenced* }\end{array}$ & $\begin{array}{l}\text { Number of } \\
\text { Grid Cells } \\
\text { Influenced } \\
(\mathrm{Abs}[r] \geq 0.2)\end{array}$ & $\begin{array}{l}\text { Percent of } \\
\text { Total Possible } \\
\text { Grid Cells } \\
\text { Influenced }\end{array}$ & $\begin{array}{l}\text { Number of Grid } \\
\text { Cells With } \\
>30 \% \text { of } \delta^{18} \mathrm{O} \\
\text { Variance } \\
\text { Explained }\end{array}$ & $\begin{array}{l}\text { Percent of Grid } \\
\text { Cells With } \\
>30 \% \text { of } \delta^{18} \mathrm{O} \\
\text { Variance } \\
\text { Explained }\end{array}$ \\
\hline Precipitation (all) & 794 & 642 & 80.9 & 173 & 21.8 \\
\hline Temperature (all) & 794 & 337 & 42.4 & 22 & 2.8 \\
\hline Precipitation (neg.: $r \leq-0.2$ ) & 794 & 591 & 74.4 & 168 & 21.2 \\
\hline Temperature (pos.: $r \geq 0.2$ ) & 794 & 99 & 12.5 & 0 & 0.0 \\
\hline Local sources & 794 & 556 & 70.0 & 180 & 22.7 \\
\hline 1, Arctic Ocean & 114 & 75 & 658 & 10 & 8.8 \\
\hline 2, Antarctica/S.Ocean & 137 & 83 & 60.6 & 12 & 8.8 \\
\hline 3, Greenland & 22 & 12 & 54.5 & 1 & 45 \\
\hline 4, North Pacıfic & 148 & 94 & 63.5 & 19 & 128 \\
\hline 5, North America & 150 & 67 & 44.7 & 4 & 27 \\
\hline 6 , North Atlantic & 171 & 82 & 48.0 & 10 & 5.8 \\
\hline 7, Eurasia & 263 & 170 & 64.6 & 17 & 6.5 \\
\hline 8, Subtropical N. Pacific & 231 & 166 & 71.9 & 38 & 16.5 \\
\hline 9, Tropical N. Atlantic & 237 & 130 & 54.9 & 7 & 3.0 \\
\hline 10 , Africa & 216 & 93 & 43.1 & 5 & 2.3 \\
\hline 11, North Indian Ocean & 140 & 90 & 64.3 & 20 & 14.3 \\
\hline 12, Equatorial Pacific & 136 & 98 & 72.1 & 45 & 33.1 \\
\hline 13 , South America & 170 & 106 & 62.4 & 7 & 4.1 \\
\hline 14, Tropical S Atlantic & 93 & 61 & 65.6 & 12 & 12.9 \\
\hline 15, South Atlantic/Indian & 305 & 213 & 69.8 & 35 & 11.5 \\
\hline 16, W. Pacific warm pool & 69 & 52 & 75.4 & 18 & 26.1 \\
\hline 17 , South Pacific & 282 & 200 & 70.9 & 52 & 18.4 \\
\hline 18 , Southern Ocean & 217 & 136 & 62.7 & 32 & 14.7 \\
\hline 19 , Australia & 74 & 44 & 59.5 & 0 & 0.0 \\
\hline
\end{tabular}

*All grid boxes are influenced by temperature, precipitation, and local moisture source; an individual vapor source region is considered to influence a grid box if it provides $\geq 2 \%$ of the total precipitation.

maps the distribution of sites and magnitudes of correlation coefficients between isotopes and temperature (Plate 5a) and precipitation (Plate 5b).

At most IAEA sites, a statistically significant correlation was found between isotopic and climatic variability (temperature, precipitation, or both). Correlations were significant at $98 \%$ starting at absolute $r$ values of about 0.15 (depending on the actual number of months in the record) and reached maxima around 0.5 (absolute values). In most cases, both temperature and precipitation had a statistically significant influence on precipitation $\delta^{18} \mathrm{O}$.

Observed temperature-isotope correlations usually reached $r$ values between 0.2 and 0.4 , consistent with our model results. Also consistent between model and observations is the geographic distribution of temperature-isotope correlations: both reveal that a significant positive relationship can occur at a variety of latitudes (not just in colder climates), although the relationship appears slightly more prevalent at higher latitudes in both cases. A significant

Plate 5. Map showing distribution of correlations between observed precipitation $\delta^{18} \mathrm{O}$ anomalies and (a) temperature and (b) precipitation, using data from the International Atomic Energy Agency [IAEA/WMO 1998]. Comparison with model results indicates significant similarity with the temperature results, but the precipitation amount- $\delta^{18} O$ correlations are much more widespread and strong in the model than in the data.
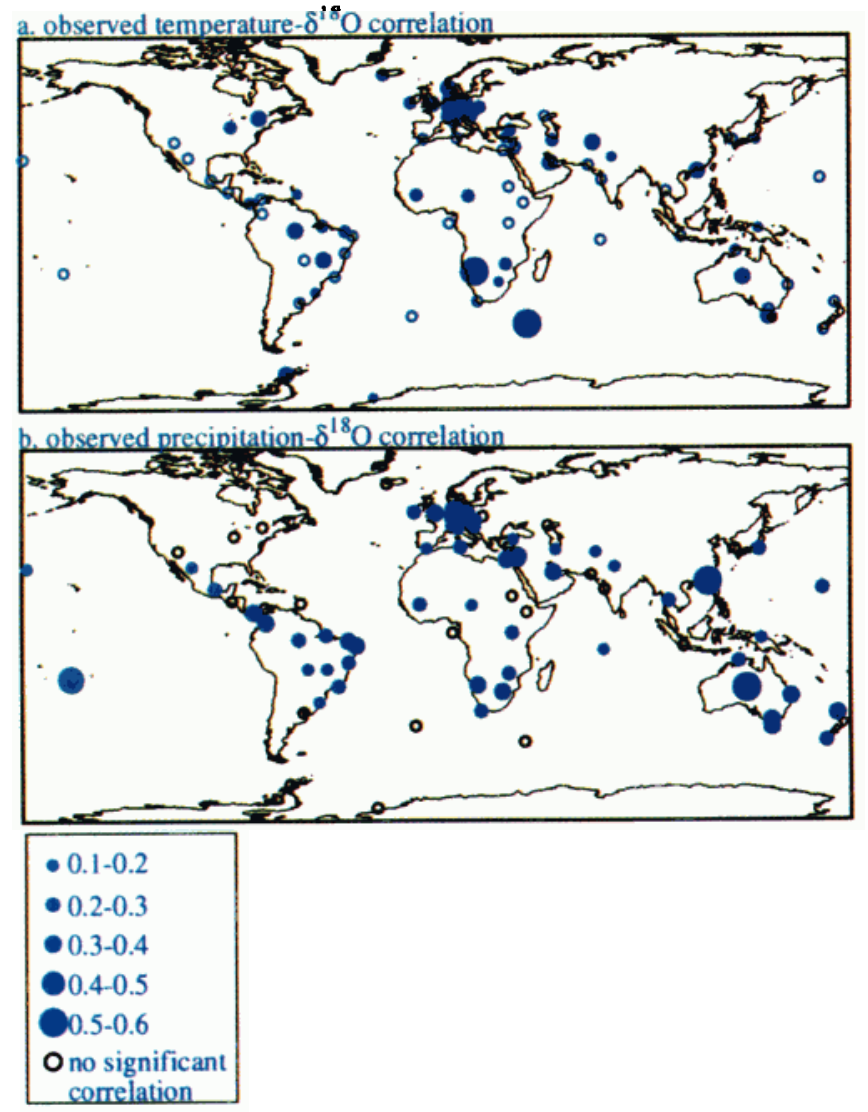

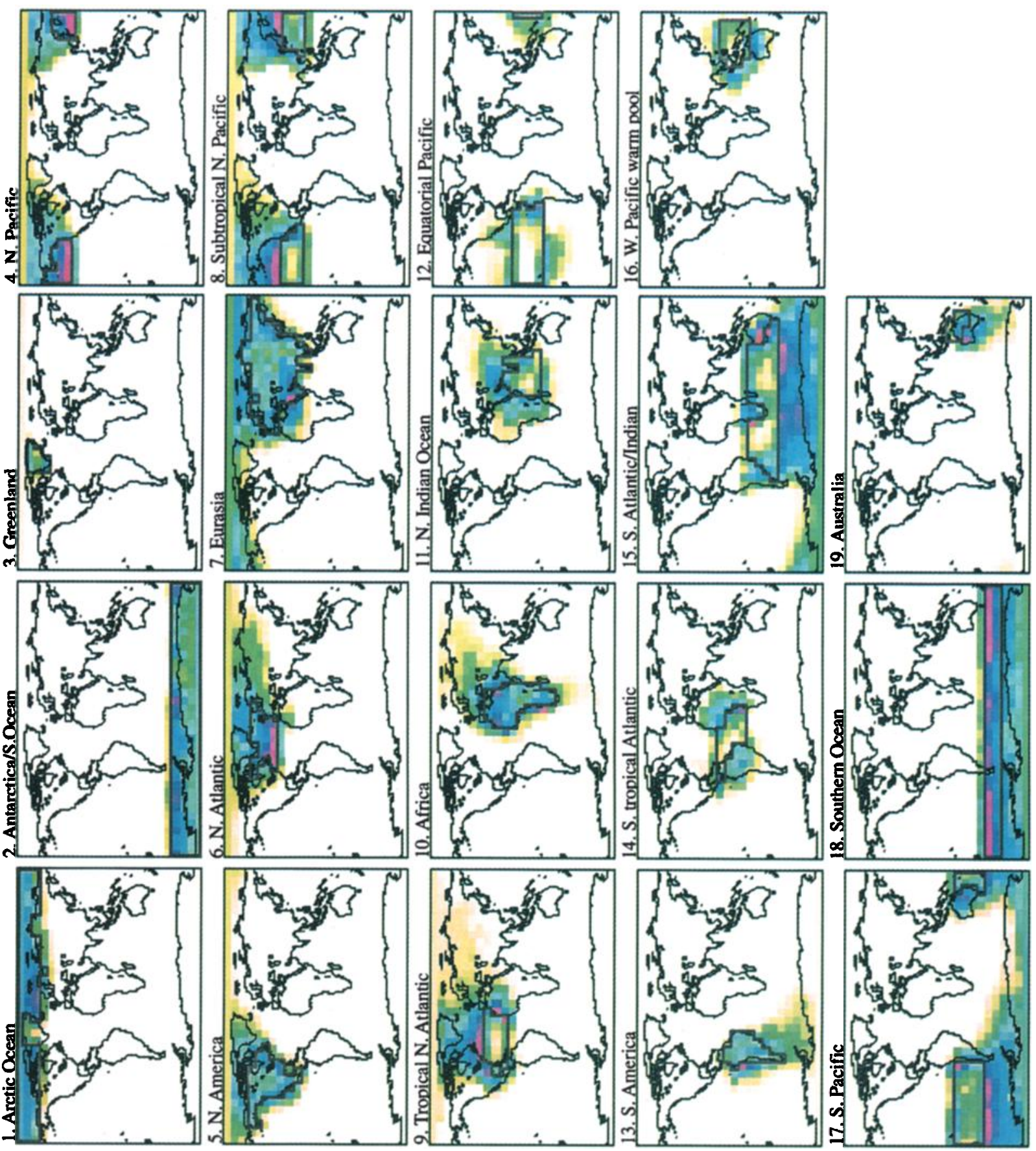

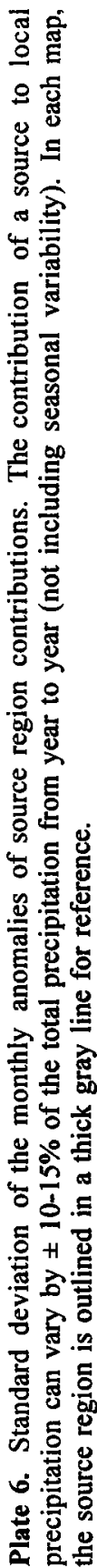

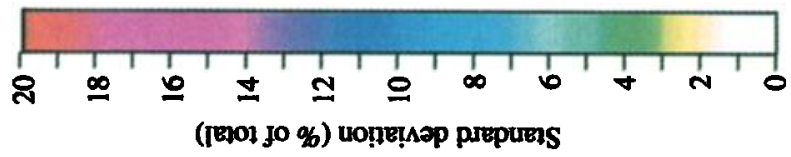


difference between the model and the observations is that the model simulates large regions of inverse temperature-isotope correlation, whereas only one instrumental station, Hong Kong, shows such a relationship. Observed precipitation amount $-\delta^{18} \mathrm{O}$ correlations reach only about -0.5 in magnitude, but this result differs from our model simulations, in which $r$ values commonly exceed -0.6 and reach -0.8 in some equatorial ocean grid cells.

In the model, precipitation-isotope correlations are stronger and more widespread than the observations indicate. This disagreement may result from inadequacies in the data, model, or both. The difference in scale between model and observations could account for stronger correlations in the model relative to observations; we are comparing measurements of monthly local precipitation amount and $\delta^{18} \mathrm{O}$ (both relatively "noisy" quantities at a specific site on a monthly scale) with mean simulated values over an $8^{\circ} \times 10^{\circ}$ grid cell. Yapp [1982], in a quantitative study of the amount effect, suggests that a strong dependence of precipitation $\delta^{18} \mathrm{O}$ on amount requires approximate constancy of the following elements of the precipitation process, on the timescale of the sampling (here monthly): initial vapor composition, initial condensation temperature, rate of vertical ascent, and ratio of condensate to vapor. Our comparison of simulated and observed amount effects implies that the model may underestimate the actual variability in one or more of these parameters.

\subsection{Simulated Climate-Isotope Relationships}

These simulations do not indicate a strong positive correlation between temperature and $\delta^{18} \mathrm{O}$ of precipitation. Precipitation and temperature variability are strongly (positively) correlated over most of the globe in this simulation, so correlation of precipitation $\delta^{18} \mathrm{O}$ with precipitation amount could mask a direct temperature-isotope relationship We applied both modeled and empirical relationships between precipitation amount and $\delta^{18} \mathrm{O}$ (based on these GCM results and on observations in the IAEA network, respectively; [Gat and Gonfiantini, 1981]) to remove the influence of precipitation amount, but these calculations did not improve the correlation between temperature and isotopic variations. Alternatively, the analysis of all months of the simulation might mask a stronger temperature-isotope relationship in some months than others. We repeated our analysis for 4 months individually (January, April, July, and October) and found that the temperature-isotope relationship is even less clear and extensive in these individual months than in the analysis of all months collectively. Using annual averages for the analysis also resulted in a weaker demonstration of temperature-isotope correlation than in the analysis of all months. Using monthly anomalies as we have, Hoffmann et al. [1998] found similar levels of temperature- $\delta^{18} \mathrm{O}$ correlation in their 10-year simulation using the ECHAM GCM.

Analyses of the temperature-isotope relationship that examine the seasonal cycle or that focus on spatial gradients tend to yield much stronger temperature-isotope correlations than we have found for either the model results or the observed IAEA data [e.g. Dansgaard, 1964; Shuman et al, 1995; Yao et al., 1996]. We suggest that the relatively low degree of correlation between temperature and isotopic variability on interannual timescales results from the mechanism by which interannual temperature variability occurs. In the model (as in the real world), year-to-year temperature anomalies occur as a consequence of changing advective patterns associated with altered sea level pressure distributions. For example, a Northern Hemisphere low pressure anomaly induces counterclockwise surface circulation, which results in southerly flow along the eastern flank that brings warmer air poleward; the opposite situation occurs on the western flank of the low, where northerly flow would bring colder air equatorward. Thus temperature changes occur in a context of changing surface flow that also alters the vapor source regions influencing a site and the mixing of air masses with different condensation histories. Advective temperature variability is a common feature of both observed and simulated climate variability and probably explains the relatively weak $(r<0.5)$ positive temperature-isotope correlations in both model results and observations. By contrast, spatial and seasonal variations (and to some extent, the longer-term glacial-interglacial changes) are largely determined by global radiative and other forcings. If such changes are sufficiently large, then the temperature dependence of fractionation factors and condensation extent can dominate other potential influences. However, advective processes are likely to have played a role on these timescales as well [Charles et al., 1994]

\subsection{Source Region Variability}

The contribution of a specified vapor source region to precipitation in nearby grid cells can be highly variable (Plate 6 ); even excluding seasonal variations, the contribution of a single source can vary by $\pm 10-15 \%$ of the total amount of precipitation in a grid cell. In other words, a grid cell may receive $30 \%$ of its precipitation from a specified vapor source region in a given month and $60 \%$ from that vapor source in the same month of the following year. Variability is highest on the edges of middle- to high-latitude oceanic sources, and generally lowest for equatorial ocean region sources, where the locally originating vapor precipitates mostly within the same region. Vapor contributions from local source regions, particularly in the low- to middle-latitude oceans, are fairly consistent from one year to the next, resulting in relatively low standard deviations over these areas.

In our simulations the isotopic effects of variations in vapor source contributions propagate long distances. For example, the contribution of subtropical Pacific moisture (source region 8) generates downstream isotopic variability in precipitation over northeastern North America, the Arctic, and even central Eurasia, in addition to its local effects. The contributions of midlatitude continental vapor (sources 5,7 , and 19) exert strong impacts on the $\delta^{18} \mathrm{O}$ of precipitation over downstream oceanic areas. Strong $(r>0.5)$ correlations between precipitation $\delta^{18} \mathrm{O}$ and specific source region contributions occur even when the source in question constitutes just a few percent of the total precipitation. From a mass balance standpoint, this result implies that the vapor originating from a remote source can be extremely isotopically depleted relative to that of local origin and that small changes in these contributions can strongly influence the isotopic variability of modern and paleoclimatic isotope records.

In general, the relative contribution of vapor from the local source (as defined in Figure 1) exerts a strong influence on 
precipitation $\delta^{18} \mathrm{O}$ in any given grid cell. As expected, most regions exhibit positive correlations between $\delta^{18} \mathrm{O}$ and local vapor; inverse relationships occur in places where local vapor may be more isotopically depleted than vapor from nearby sources (e.g., over Antarctica or in equatorial regions of convective precipitation adjacent to the more arid subtropics). The influence of changing vapor source regions also varies over the course of the seasonal cycle (not shown). The contribution of vapor from land sources tends to exert broadest influence during local summer, when evapotranspiration is seasonally highest, although correlations with isotopic variability are not necessarily higher. Thus the processes that dominate isotopic variability at a single site may change over the course of typical year.

The map of local source- $\delta^{18} \mathrm{O}$ correlation (Plate 4 , bottom right-hand panel) exhibits strips of low correlation on the windward side of oceanic sources. This pattern occurs most likely as an artifact of how we defined vapor source regions: in those strips, most of the vapor should originate from the source immediately upstream ("nonlocal" by our imperfect definition) yet that vapor has not become isotopically depleted by lengthy transport. Thus shifts between local and this neighboring "nonlocal" vapor source contributions will have no isotopic impact, and source- $\delta^{18} \mathrm{O}$ correlations are low. Similarly, strong source- $\delta^{18} \mathrm{O}$ correlations are seen on the immediate leeward side of source regions, probably because the total vapor consists of mostly the adjacent upstream source, but what little other vapor is present has been transported for relatively long distances and has become strongly fractionated. Thus the overall precipitation $\delta^{18} \mathrm{O}$ is sensitive to small changes in the mixture of these components, and the correlation is strong.

Source region contributions are not independent from local temperature and precipitation changes, but neither are they correlated with these parameters in a simple, unidirectional manner. For example, in a given region an increase in the contribution of the local vapor source tends to correlate with lower precipitation amount and lower temperature. The first two factors would tend to increase precipitation $\delta^{18} \mathrm{O}$; the latter would decrease it. In addition, we observe correlations between climate and non-local vapor source contributions that are consistent with advection. The relative contribution of a given vapor source region tends to correlate positively with temperature on the poleward side of that source region (a result of enhanced poleward flow of warmer air transporting vapor from that source) and inversely on the equatorward side of that region (a result of equatorward flow of cooler air transporting vapor). Thus the isotopic influence of source region variability is overlain on the isotopic effects of local temperature and precipitation in ways that may either enhance or attenuate the expected climateisotope relationships.

\section{Conclusions}

Our results suggest that interannual variability in precipitation $\delta^{18} \mathrm{O}$ results from the interaction of many aspects of climate, including a significant contribution from changing vapor source regions. In agreement with observations, the simulated relationship between temperature and isotopic variability (in monthly anomalies) is particularly tenuous over most of the globe, although direct temperature-isotope correlations are strongest over middleand high-latitude continents. The influence of precipitation amount on $\delta^{18} \mathrm{O}$ is strong over the oceans, particularly in the tropics but also at higher latitudes; this effect is stronger in the model than in observations. The simulated contributions of specified vapor source regions to precipitation vary widely from month to month and exert significant isotopic influence, even in regions where a given source provides only a few percent of the total moisture. Source $-\delta^{18} \mathrm{O}$ correlations tend to weaken over continents. Except for a moderate relationship to temperature, isotopic variability over continents (where most paleoisotopic records are located) is not strongly coupled to an individual climatic forcing factor. Instead, it probably reflects either a shifting combination of factors or factors that we have not considered.

A recent study of Greenland ice core isotopic variability over the past several centuries reached similar conclusions on the relationship of precipitation $\delta^{18} \mathrm{O}$ to local climate. White et al. [1997] found correlation of a regional, annual $\delta^{18} \mathrm{O}$ composite record to be less than 0.5 with any individual climate factor. However, a combination of climate factors including inferred vapor source region characteristics, local circulation indices, temperature, and solar irradiance yielded a multivariate correlation of 0.71 . Our results are not directly comparable to the observed isotopic data on Greenland, as the $8^{\circ} \times 10^{\circ}$ resolution of this GCM is insufficient to capture important details such as elevation, continentality, and seasonal isotope cycle in Greenland [Jouzel et al., 1987]. However, the argument that isotopic data reflect a multivariate climate picture, including significant information about vapor source and large-scale circulation patterns, is wholly consistent with our results.

\subsection{Scales of Variability: A Hierarchy of Controls}

Both in nature and in the model, interannual temperature changes usually reflect advective processes: they result from a changed distribution of atmospheric pressure that initiates changes in surface flow patterns, bringing either warmer or cooler air into a region (and involving concurrent changes in air mass mixing, vapor sources, and transport histories). This style of temperature variability differs markedly from, for example, seasonal precipitation $\delta^{18} \mathrm{O}$ changes, or changes associated with the cooling during the last ice age, in which temperatures were lowered globally. GCM simulations of the last glacial maximum support a global reduction of precipitation $\delta^{18} \mathrm{O}$ values at that time that is consistent with expected temperature-isotope relationships [Jouzel et al., 1994; Hoffmann et al., 1999], although the slope of the temperature-isotope relationship appears to vary [Jouzel et al. 1997]. We suggest a continuum of controls on precipitation $\delta^{18} \mathrm{O}$ in which smaller, advective temperature changes tend to correlate weakly or not at all with $\delta^{18} \mathrm{O}$ changes, while periods of large-scale temperature change are likely to generate an isotopic signal more consistent with the standard paleotemperature interpretation. Of course, advective changes associated with global temperature shifts will add variability to the hypothesized temperature-isotope relationship at a given site [Charles et al., 1994]. The challenge remains to determine how the influence of these factors is manifested at intermediate scales of variability. Longer GCM simulations that include isotopic tracers may reveal a stronger temperature-isotope relationship at decadal- 
centennial scales, and longer observational records (both instrumental and paleoclimatic) will also shed light on the climate-isotope relationship at these intermediate scales.

Many paleoclimatic archives (e.g., ice cores, tree rings, corals, lake/bog sediments, and cave deposits) preserve information about the isotopic composition of precipitation that has been interpreted in terms of past climate variations. Our results argue for a complex combination of factors influencing isotopic variability and for the need to consider variations in the relative contributions of vapor sources when interpreting paleoisotopic records in terms of climatic changes. Although vapor source regions are difficult, if not impossible, to document by observation, an understanding of variability in advective parameters such as wind direction and storm tracks may help to constrain source region contributions to precipitation at a given site. Calibration of isotopic records with advective parameters may in turn enrich the value of these records as paleocirculation indicators.

Using a GCM to explore the relationship between isotopic and climatic variability offers insight not available from observations. Long, continuous time series of isotopic data for modern precipitation are scarce and sparsely distributed [Rozanski et al., 1993]. A detailed, global documentation of geographic vapor source contributions is not available from climatic observations. The tracer GCM allows us to generate a global picture of isotopic and source region variability and to assess how these interact and relate to other climatic factors. Validation of these relationships is difficult, given the lack of global, long-term observations, but the processes we identify as significant are consistent with isotopic theory and likely exert a strong influence on the paleoisotopic record of recent climate variability. The important role that we propose for source region variability in determining the interannual variability of precipitation $\delta^{18} \mathrm{O}$ can be tested by experiments using tracer GCMs with different transport schemes and higher spatial resolution and by incorporating advective climate parameters (e.g., wind direction, storm tracks) into calibration and analysis of observed isotopic variations in precipitation.

Acknowledgments. The manuscript benefited greatly from review by Georg Hoffmann, Jonathan Overpeck, and Eric Steig, and from ongoing discussion and collaboration with Randy Koster, Jim White, and Renaud Mathieu. We are grateful to the National Science Foundation, the Department of Energy NIGEC program, and the NOAA Paleoclimatology Program for support and computing resources. Comments by anonymous JGR reviewers greatly improved this paper.

\section{References}

Bromwich, D. H., Snowfall in high southem latitudes, Rev. Geophys., 26, 149-168, 1988.

Bromwich, D. H., and C. J. Weaver, Latitudinal displacement from main moisture source controls $\delta^{18} \mathrm{O}$ of snow in coastal Antarctica, Nature, 301, 145-147, 1983

Brubaker, K. L., D. Entekhabi, and P. Eagleson, Estimation of continental precipttation recycling. J. Clim., 6, 1077-1089, 1993.

Brubaker, K. L., D. Entekhabi, and P. Eagleson, Atmospheric water vapor transport and continental hydrology over the Americas, $J$ Hydrol , 155, 407-428, 1994

Charles, C. D., D. Rınd, J. Jouzel, R. D. Koster, and R. G Fairbanks, Glacial-Interglacial changes in moisture sources for Greenland: Influences on the ice core record of climate, Sctence, 263, 508-511, 1994.
Cole, J. E., Interannual-decadal variability in tropical climate systems: Stable isotope records and general circulation model experiments, Ph.D. thesis, Columbia University, New York, 1992.

Cole, J. E., D. Rind, and R. G. Fairbanks, Isotopic responses to interannual climate variability simulated by the GISS GCM, Quat. Sci Rev, 12, 387-406, 1993.

Cuffey, K. M., R. B. Alley, P. M. Grootes, J M. Bolzan, S. Anandakrishnan, Calibration of the $\delta^{18} \mathrm{O}$ isotopic paleothermometer for central Greenland, using borehole temperatures, J. Glaciol., 40, 341-349, 1994.

Dansgaard, W., Stable isotopes in precipitation, Tellus, 16, 436-468, 1964.

Dansgaard, W., J. W. C. White, and S. J. Johnsen, The abrupt termination of the Younger Dryas event, Nature, 339, 532-534, 1989.

Eltahir, E. A. B., and R. L. Bras, Precipitation recycling, Rev. Geophys., 34, 367-378, 1996.

Fischer, D. A., and B. T. Alt, A global oxygen isotope model-semiempirical, zonally averaged, J. Glaciol, 7, 117-124, 1985.

Gat, J. R., The isotopes of hydrogen and oxygen in precipitation, in Handbook of Environmental Isotope Geochemistry, 1. The Terrestrial Environment, edited by P. Fritz and J. C. Fontes, pp. 21-47, Elsevier, New York, 1980.

Gat, J., and R Gonfiantini, Stable Isotope Hydrology: Deuterium and Oxygen-18 in the Water Cycle, Int. At. Energ. Agency, Vienna, 1981.

Gedzelman, S. D., and J. R. Lawrence, The isotopic composition of cyclonic precipitation, J. Appl. Met., 2I, 1385-1404, 1982.

Grootes, P. M., M Stuiver, L. G. Thompson, and E. Mosley-Thompson, Oxygen isotope changes in tropical ice, Quelccaya, Peru, $J$. Geophys Res., 94, 1187-1194, 1989.

Hansen, J., G. Russell, D Rind, P Stone, A. Lacis, S. Lebedeff, R. Ruedy, and $L$. Travis, Efficient three-dımensional global models for climate studies, models I and II, Mon. Weather Rev., 111, 609-662, 1983.

Hoffmann, G. and M. Heimann, Water tracers in the general circulation model ECHAM, MPI Rep. II0, 13 pp., Max-Planck-Inst. für Meteorol., Hamburg, 1993.

Hoffmann, G., G. Werner, and M. Heimann, Water isotope module of the ECHAM atmospheric general circulation model: A study on timescales from days to several years, J. Geophys. Res., 103, 16,871-16,896, 1998 .

Hoffmann, G., V. Masson, and J. Jouzel, Stable water isotopes in atmospheric general circulation models, J. Hydrol., in press, 1999.

Ingraham, N L, and B. E. Taylor, Light stable isotope systematics of large-scale hydrologic regimes in Califomia and Nevada, Water Resour. Res., 27, 77-90, 1991

International Atomic Energy Agency/World Meteorological Organization (IAEA/WMO), Global Network for Isotopes in Precipitation, The GNIP Database, Release 2 May 1998, URL: http://www.iaea.org/programs/ri/gnip/gnipmain.htm.

Joussaume, $\mathrm{S}$, and J. Jouzel, Paleoclimatic tracers: An investigation using an atmospheric general circulation model under Ice Age conditions, 2, Water isotopes, J. Geophys. Res., 98, 2807-2830, 1993.

Joussaume, S, R. Sadourny, and J. Jouzel, Water isotope cycles in the atmosphere First simulation using a general circulation model, Nature. 31l, 24-29, 1984.

Joussaume, S, R. Sadourny, and C. Vignal, Origin of precipitating water in a numerical sımulation of the July climate, Ocean Air Interactions, I, 43-56, 1986

Jouzel, J., and L. Merlıvat, Deuterium and oxygen 18 in precipitation Modeling of the isotopic effect during snow formation, $J$. Geophys. Res., 89, 5015-5030, 1984.

Jouzel, $\mathrm{J}$ et al., Validity of the temperature reconstruction from water isotopes in ice cores, J. Geophys. Res., 102, 26,471-26,487, 1997.

Jouzel, J., G. L. Russell, R. J. Suozzo, R. D. Koster, J W. C. White, and W. S. Broecker, Simulations of the HDO and $\mathrm{H}_{2}{ }^{1 \mathrm{~B}} \mathrm{O}$ atmospheric cycles using the NASA GISS general circulation model: The seasonal cycle for present-day conditions, $J$ Geophys. Res., 92, $14,739-14,760,1987$.

Jouzel, J., R. D. Koster, R. J. Suozzo, G. L. Russell, J. W. C White, and W. S. Broecker, Simulations of the $\mathrm{HDO}$ and $\mathrm{H}_{2}{ }^{18} \mathrm{O}$ atmospheric cycles using the NASA GISS general circulation model- Sensitivity experiments for present-day conditions, $J$. Geophys. Res., 96, 74957507,1991

Jouzel, J., R. D. Koster, R. J Suozzo, and G. L Russell, Stable water isotope behavior during the last glacial maximum: A GCM analysis, $J$ Geophys Res., 99, 25,791-25,801, 1994 
Koster, R D, D P de Valpine, and J. Jouzel, Continental water recycling and $\mathrm{H}_{2}{ }^{1 \mathrm{~B}} \mathrm{O}$ concentrations, Geophys. Res. Lett., 20, 22152218,1993

Koster, R D., J Jouzel, R. J. Suozzo, G. L. Russell, W. S. Broecker, D. Rind, and P. Eagleson, Global sources of local precipitation as determined by the NASA/GISS GCM, Geophys. Res. Lett., 43, 121124, 1986.

Krinner, G., C Genthon, and J. Jouzel, GCM analysis of local influences on ice core d signals, Geophys. Res. Lett, 24, 2825-2828, 1998.

Peixoto, J P., and A. H. Oort, Physics of Climate, 520 pp., Am. Inst. of Phys., New York, 1993.

Petit, R. R., J. W. C. White, N. W. Young, J. Jouzel, and Y. S. Korotkevich, Deuterium excess in recent Antarctic snow, $J$. Geophys. Res., 96, 5113-5122, 1991.

Rozanski, K., C. Sonntag, and K O. Munnich, Factors controlling the stable isotope concentration of European precipitation, Tellus, 34, 142-150, 1982.

Rozanski, K., L. Araguas-Araguas, and R. Gonfiantini, Relationship between long-term trends of oxygen-18 isotope composition of precipitation and climate, Science, 258, 981-985, 1992.

Rozanski, K., L. Araguas-Araguas, and R. Gonfiantini, Isotopic patterns in modern global precipitation, in Climate Change in Continental Isotopic Records, Geophys. Monogr. Ser. vol. 78, edited by P. Swart, K. C. Lohmann, J McKenzie and S Savin, pp. 1-36, AGU, Washington D. C., 1993.

Salati, E., A. Dall'Olio, E. Matsuı, and J. R. Gat, Recyclıng of water in the Amazon Basin: An isotopic study, Water Resour Res, 15, 12501258,1979

Salati, E., and P B. Vose, Amazon Basin A system in equilibrium, Science, 225, 129-138, 1984.

Shuman, C. A., R. B. Alley, S. Anandakrishnan, J. W. C. White, P. W. Grootes, and C. R. Stearns, Temperature and accumulation at the Greenland Summit: Comparison of high-resolution isotope profiles and satellite passive microwave brightness temperature trends, $J$. Geophys. Res., I00, 9165-9177, 1995.
Steig, E. J., P. M. Grootes, and M. Stuiver, Seasonal precipitation timing and ice core records, Sclence, 266, 1885-1886, 1994.

White, J. W. C., L. K. Barlow, D. Fisher, P. Grootes, J. Jouzel, S. J. Johnsen, M. Stuiver, and H. Clausen, The climate signal in the stable isotopes of snow from Summit, Greenland: Results of comparisons with modern clımate observations, $J$. Geophys. Res., 102, 26, 42526,439, 1997

Yakir, D., S. Lev-Yadun, and A. Zangvil, El Niño and tree growth near Jerusalem over the last 120 years, Global Change Biol., 2, 97-101, 1996.

Yao, T., L. G. Thompson, E. Mosley-Thompson, Y. Zhihong, Z. Xingping, and P.-N. Lin, Climatological significance of $\delta^{18} \mathrm{O}$ in north Tibetan ice cores, J. Geophys. Res., IOI, 29,531-29,537, 1996.

Yapp, C. J., A model for the relationships between precipitation D/H ratios and precipitation intensity, $J$. Geophys. Res., 87, 9614-9620, 1982.

Zimmerman, U., D. Ehhalt, and K. O. Munnich, Soil water movement and evapotranspiration: Change in the isotopic composition of the water, in Isotopes in Hydrology, pp. 567-585, IAEA, Vienna, Austria, 1967.

J. E. Cole, Campus Box 450, University of Colorado, Boulder CO 80309. (coleje@gspot.colorado.edu)

D. Rind, NASA/GISS, 2880 Broadway, New York, NY 10025. (drind@giss.nasa.gov)

R. S. Webb, NOAA/NGDC Paleoclimatology, 325 Broadway E/GC Boulder CO 80303 (rsw@ingdc.noag.gov)

J. Jouzel, Laboratoire des Sciences du Climat et de l'Environnement UMR CEA-CNRS 1572, CEA Saclay, Orme des Merisiers, 91191 Gif sur Yvette, France (iouzel(Oobelix.saclay.cea.fr)

R. Healy, Marıne Chemistry \& Geochemistry MS 25, Woods Hole Oceanographic Institution, Woods Hole, MA 02543. (rhealy@) whoi.edu)

(Received August 8, 1998, revısed February 23, 1999; accepted March 4, 1999) 